\title{
Counterpoint: clinical neuroscience is not ready for clinical use
}

\author{
Mark D. Rego
}

\section{Summary}

Radical proposals are being made to change the practice, teaching and research basis of psychiatry to that of clinical neuroscience. Such changes would affect practice via what is studied, published, recommended as standard treatment and what is decided in medico-legal forums. These proposed changes are very premature and misguided. Here, I refute these proposals.

\section{Declaration of interest}

None.

\section{Copyright and usage}

(c) The Royal College of Psychiatrists 2016.
Mark D. Rego is an assistant clinical professor of psychiatry in the Yale School of Medicine.

In recent years the psychiatric literature has contained several prominent opinion pieces which propose to change the way psychiatry is practised and taught. ${ }^{1,2}$ These authors contend that neuroscience has progressed to the point that psychiatry should either merge with neurology or become a specialty of clinical neuroscience. I believe this is premature.

\section{History}

Psychiatric neuroscience came of age in the 1990s when neuroimaging and genetic testing - along with more advanced molecular studies of receptors, messenger systems, etc. - were applied in aggressive research programmes to psychiatric disorders. It can be stated with no controversy that in the 25 years since, in spite of a large accumulation of data, we do not know the cause for any psychiatric disorder. We know many associations with neuroscientific findings, but the theories these generate remain far from proven.

Furthermore and more to the point we have no diagnostic tests or biomarkers (the dementias are exceptions to all I am about to say). There are also no tests for prognosis, treatment choice or treatment response. In all cases there are studies showing associations, but none that do better than clinical assessment. Even for the tests that do show promising associations, the explained degree of variance between participants and controls is usually small enough that the test could not even serve as an adjunct to clinical evaluation.

The final area of promise in neuroscience has been the development of new drugs for psychiatric disorders. Again, there has been no progress on this front. Even the neuroscientifically generated hypotheses about drugs that are already available have not borne out (an example would be naltrexone for the treatment of borderline personality disorder ${ }^{3}$ ).

Neuroscientists can hardly be blamed for this record. The massive complexity of the brain still baffles all of science. The most basic things like how structure and function are related remain mysterious (even leaving alone the problem of how consciousness exists). No one knows where or how information is stored, in what format, or how it is retrieved and processed.

Rather than be a clinical neuroscience, psychiatry is an eclectic use of tools from different disciplines to help those with mental disorders and other emotional and cognitive problems. Situated in the centre of this endeavour are psychopathology, normal psychology and neuropsychology. These all currently rely on construct validity ${ }^{4}$ not on aetiological explanations. To be sure neuroscience plays an important role in construct validity, as do descriptive studies, epidemiology, genetics, medication response and cognitive neuroscience. Additionally, psychopharmacology depends heavily on receptor science as well as clinical neurology. We all would like to see and appreciate the need for biological progress in all the areas I have mentioned. But needing these things and having them are quite different.

\section{What we know}

We should be mindful of the areas in which neuroscience has changed our thinking about psychiatry. As mentioned above, neuroscience has added to the ongoing work in construct validity in many areas. These include, but are not limited to, psychopathology; neuropsychology (e.g. the better understanding of memory systems ${ }^{5}$ ); appreciation of the complexity of psychiatric genetics; the knowledge that successful psychotherapy has concrete neurophysiological impact; ${ }^{6}$ the growing literature on new neuropsychological concepts such as salience ${ }^{7}$ and conclusion formation, which better connect pathology to normal function, and the shift in focus from the limbic system to the prefrontal cortex as an essential part of all psychopathology (and within this refocus a better understanding of the prefrontal cortex such as the complementary functions of the dorsal and ventral frontal systems). Last, I will mention the development in thinking about the genesis of mental illness that was unclear and controversial as recently as the 1980s. Were the syndromes we commonly observed complex psychological problems, undiagnosed medical disorders or many different psychiatric illnesses? Because of neuroscience research as well as clinical investigation we now know that most mental illness includes some degree of inherited vulnerability that can be modified positively or negatively by experience and may or may not express itself in the form of a final common pathway due to stress or developing vulnerability.

This misattribution of the role of neuroscience is doubly a shame as there is much to advertise about the way we now conduct treatment. The combination of empirically validated constructs, many choices of medicines to work with, multiple forms of validated psychotherapy as well as empirically tested social interventions such as assisted employment ${ }^{8}$ now equip us 
with the tools to either remit or mitigate the suffering of most patients at the same level as many medical specialties. Psychiatry and allied mental health disciplines have much to offer in the form of relatively safe, inexpensive, empirically based and clinically reasoned treatments for very common and debilitating health problems. Psychiatry has long been the object of scepticism from the public, potential patients and our colleagues. Clarity on all we have to offer is in order.

Mark D. Rego, MD, Yale University School of Medicine, 63 Lookout Hill Road, Milford, CT 06461, USA. Email: mark.rego@yale.edu

First received 4 Jun 2015, accepted 30 Sep 2015

\section{References}

1 Ross DA, Travis MJ, Arbuckle MR. The future of psychiatry as clinical neuroscience: Why not now? JAMA Psychiatry 2015; 72: 413-4.
2 Reynolds CF, Lewis DA, Detre T, Schatzberg AF, Kupfer DJ. The future of psychiatry as clinical neuroscience. Acad Med 2009; 84: 446-50.

3 Bohus MJ, Landwehrmeyer GB, Stiglmayr CE, Limberger MF, Böhme R Schmahl CG. Naltrexone in the treatment of dissociative symptoms in patients with borderline personality disorder: an open-label trial. J Clin Psychiatry 1999; 60: 598-603.

4 Feighner JP, Robins E, Guze SB, Woodruff Jr RA, Winokur G, Munoz R. Diagnostic criteria for use in psychiatric research. Arch Gen Psychiatry 1972; 26: 57-63.

5 Budson AE, Price BH. Memory dysfunction. N Engl J Med 2005; 352: 692-9.

6 Collerton D. Psychotherapy and brain plasticity. Front Psychol 2013; 4 548.

7 Menon V. Large-scale brain networks and psychopathology: a unifying triple network model. Trends Cogn Sci 2011; 15: 483-506.

8 Kinoshita Y, Furukawa TA, Kinoshita K, Honyashiki M, Omori IM, Marshall M, et al. Supported employment for adults with severe mental illness. Cochrane Database Syst Rev 2013; 9: CD008297.

\section{A Theory of Human Motivation by Abraham H. Maslow (1942)}

\section{Kevin Healy}

Maslow's hierarchy of human motivation is an often-cited reference in articles on the practice of psychotherapy. When approached to contribute these reflections I realised that I had never actually read Maslow's original work. On then reading this very short booklet, I was surprised to see that it was written in 1942, in the middle of World War II, and yet still seemed up to date and prescient in its content, if not in its wording and style.

'When we ask what a man wants from life we deal with his very essence', according to Maslow. While Maslow recognises that an act typically has more than one motivation, he goes on to build a hierarchy of human motivation whereby the appearance of one need usually rests on the prior satisfaction of another need. He states that behaviour is almost always biologically, culturally and situationally determined as well.

I have had clinical experiences of working as a consultant psychiatrist in medical psychotherapy over the past 30 years with a variety of patients, in a variety of settings, and using a variety of constantly evolving therapeutic skills. According to Maslow, the underlying motivation in all humans is the satisfaction of the physiological needs that support homeostasis. He next describes the need for safety, which is especially evident in children as they enjoy and seek a predictable, orderly world in which to thrive. Next comes the need for love, which involves both giving and receiving love, and is not synonymous with sex. When the above needs are satisfied the need for esteem, a desire for stable, firmly based, high and respectful evaluation of the self, comes to prominence. Finally then comes the need for self-actualisation, as a man must be what he can be to be happy, to be self-fulfilled, and be everything that he is capable of becoming.

Maslow anticipated much of the literature that was to begin to follow some 20 years later on child abuse by describing the impact on children of parental quarrelling, physical assault, separation, divorce and death in the family. He noted that completely rejected children may cling to their hating parents more for sheer safety and protection than because of their hope of love. He thus began to anticipate the work of John Bowlby on attachment when he wrote that 'strong people' are likely to have been satisfied in their basic needs throughout their lives, particularly in their earlier years, and have developed exceptional powers to withstand present or future thwarting of these needs. Those who have loved and been well loved, and have many deep friendships, can hold out against hatred, rejection or persecution. It seemed probable to Maslow that the most important gratifications come in the first two years of life. People who have been made strong and secure in the earliest years tend to remain secure and strong thereafter in the face of whatever threatens.

This truly is a remarkable work that highlights the development and evolution of a range of important child developmental ideas. I am glad to have finally read it! 